\title{
Görsel Sanatlar Öğretimi Dersi Uygulama Çalışmalarında Estetik Kaygının Giderilmesinin Sınıf Öğretmeni Adaylarının Derse Karşı Tutumlarına ve Çalışmalarına Etkisi
}

\section{The Effect of Eliminating Aesthetical Concerns in Teaching of Visual Arts Courses to Preservice Primary School Teachers' Approaches to Course and Their Works}

\author{
Mukadder ÖZDEMIR BALAKOĞLU1', Muhammet Fatih DOĞAN²
}

Geliş Tarihi/Received: 02/06/2018| Kabul Tarihi/Accepted: 30/12/2018 | Yayın Tarihi/Published: 15/01/2019

\begin{abstract}
Özet: Bu araştırmanın amacı Görsel Sanatlar Öğretimi dersinde sınıf öğretmeni adaylarına uygulanan ve araştırmacılar tarafından geliştirilen uygulama metodunun, öğrencilerin derse karşı tutumlarına ve çalışmalarına etkilerini ortaya koymaktır. Geliştirilen metot Yıldız Teknik Üniversitesi Eğitim Fakültesinde 2017 - 2018 öğretim yılı güz döneminde öğrenim görmekte olan 34 ve 26 kişilik iki ayrı sınıf öğretmenliği öğrenci grubuna uygulanmıştır. Birinci grup öğrencilerde uygulama çalışmasında estetik kaygıların giderilmesini sağlayan uygulama metodu ile çalışılmış, İkinci grup öğrencilerde ise klasik uygulama metotlarına bağlııkla ders yürütülmüştür. Uygulanan metodun etkileri öğrencilere sorulan açık uçlu sorularla ortaya koyulmuş ve iki grubun derse karşı tutumu karşılaştırılmıştır. Öğrencilerden alınan verilerden uygulanan metodun olumlu etkisini destekleyen bulgulara varılmıştır. Bu uygulama aracılığı ile öğrencilerin derse karşı tutumları ümit verici düzeyde farklılaşmış, derse ilgileri artmıştır. Ayrıca öğrencilerin sanatsal farkındalık düzeylerinde, duyuşsal algılarında, sanatsal öğrenmelerinde ve hatta bilişsel algılarında gelişme olduğunu doğrulayan bulgular elde edilmiştir. Araştırma deneysel bir çalışmadır. Uygulama sonucundaki ürünler ve araştırma verilerinden elde edilen bulgular, uygulanan metodun sanat eğitiminin amaçlarını geliştirmede ekonomik bir etkisi olduğunu düşündürmektedir. Uygulanan sanatsal uygulama metodunda oluşturulan öğrenme yaşantılarının sınıf öğretmeni adaylarının mesleki tutumlarını olumlu yönde etkileyeceği yordanmaktadır.
\end{abstract}

Anahtar Kelimeler: Sanat Uygulaması, Estetik Kaygı, Sanatsal Öğrenme.

Abstract: The aim of this research is to determine the effects of the method that is applied in Teaching in Visual Arts courses to preservice primary school teachers and developed by researchers, on the students' approaches to the course and their works. The developed method was implemented to two groups of students in Bachelor degree of Primary Teacher Education consisting of 34 and 26 students. The first group was lectured with the method of eliminating aesthetical concerns, whereas the second group was lectured with adherence to classical methods. The effects of the method was observed with open ended questions to compare the approaches of these groups to the lecture. The data compiled from the students support the positive influences of the method to the students' approaches to the course. Through this method students' approach to the lecture was promisingly altered and their attention to the course was increased. Moreover data verified an improvement on students' artistic awareness, affective perception, artistic learning and even their cognitive abilities. This study is an experimental study. The products of the study and the findings derived from research data reveals that the method used is economic in advancing the purposes of art education. It could be said that the learning experiences created by this method of teaching art will have a positive impact on the professional careers of the students.

Keywords: Art Application, Aesthetic Anxiety, Artistic Learning

Önerilen Atıf Bilgisi/To Cite This Article: Özdemir Balakoğlu, M., Doğan, M. F. (2019). Görsel Sanatlar Öğretimi Dersi Uygulama Çalışmalarında Estetik Kaygının Giderilmesinin Sınıf Öğretmeni Adaylarııın Derse Karşı Tutumlarına ve Çalışmalarına Etkisi. Temel Eğitim Dergisi, 1(1), 27-39.

\footnotetext{
${ }^{1}$ Yıldız Teknik Üniversitesi Eğitim Fakültesi Temel Eğitim Bölümü, İstanbul, Türkiye, mukadderozdemir@yahoo.com

${ }^{2}$ Yıldız Teknik Üniversitesi Eğitim Fakültesi Temel Eğitim Bölümü, İstanbul, Türkiye, mfdogan@yildiz.edu.tr
} 


\section{Summary}

\section{Introduction}

In recent years, new and contemporary approaches in the field of art education have gained importance with new perspectives which deal with art education with its own disciplines and teachable dimension. Artistic learning in this sense is now a learning field where creativity is combined with creativity, which is organized and interpreted. With new orientations, art education expands its boundaries as an area of activities and teachable discipline for recognizing and exploring the many possibilities and possibilities of craftsmanship and talent. For the adoption and expansion of these contemporary approaches, there is a need to develop artistic production practices that reflect new orientations. Thanks to these contemporary tendencies today, it is believed that artistic learning can be done by verbally expressing what it can and can do, which necessitates being objective. As targeted in our artistic education; If we want to educate individuals who understand about arts, who can adopt works and contribute to the culture they are living in this way, there is a need to share researches and findings that contribute to the realization of these goals. This study is limited to evaluating the effect of a method developed and applied for visual arts teaching course on student attitude. The students who are thought to be able to overcome this problem have been focused on the obstacles stemming from their anxieties and attitudes and they have been the basis for the students to get rid of these concerns and to develop positive attitudes. It is aimed that pre-service primary teachers whose work will serve as primary teachers and who will carry out Visual Arts courses in primary schools will reach the desired goals of the education specified in the curriculum of the course. The application includes the expression of thinking through drawing and drawing, picture reading and narration, drawing and drawing, drawing, drawing and drawing, painting, drawing and drawing, drawing techniques in the curriculum.

\section{Method}

This study was carried out in the course of Visual Arts Teaching which 3 hours in a week, which was taught in Yildiz Technical University Faculty of Education Primary Teaching undergraduate program in 2017-2018 academic year in the fall semester. During the first and second weeks of the study, the first application was completed in six lesson hours. The third week students were examined together, and the open-ended questions were asked to the students and opinions and thoughts about the study were taken. 34 students attending courses in the first group and 26 students attending courses in the second group participated in the study. The frequency distribution of the responses to the questions and the results of the two groups were compared. The study forms the integrity with the application methods and the questions directed to the students gain meaning depending on the applications. For this reason, it is appropriate to disclose the method properly. To provide this and to narrow the envelope as narrowly as possible, the work is limited to being able to create compositions only with line elements. In later practice sessions, composition was created by applying pastel and watercolor techniques. These artistic production studies have also been taught with different methods that will lead to student concerns. However, other techniques are excluded from the study because they require different questions and techniques. This research is an experimental work. The questions used in the collection of data in the study were developed by the researchers in accordance with the objectives of the course. This research is a case study and has been carried out in the post-implementation descriptive analysis model. Students' responses to the questions were displayed in frequency $(f)$ and percentage tables and descriptive interpretations were made towards the low point of the high point. 
Temel Eğitim Dergisi / Journal of Primary Education, 2019, 1(1), 27-39

\section{Results}

The question we asked to learn about the past applications of the students was that $73 \%$ of the first group students did not apply even after primary school or even in primary school and $26 \%$ answered that they had the latest application in secondary education. $65 \%$ of the students in the second group stated that they did not apply after primary school and $34 \%$ stated that they were in the practice study. At the beginning of the application period, in the middle, at the end "how you felt yourself" was asked open-ended in order to make sense of the student's own expressions. When the findings are examined; it was seen that there was no significant difference in the students who felt themselves excited at the beginning of the process. Students are also directed to the question "Is your work original, imitation, why?" This question shows that the method we developed for the first group is $100 \%$ successful and that the ratio of $75 \%$ in the second group Show work also important in both groups. We asked the students "Is the practice of Visual Arts Teaching Course that effect of learning experience?" In the first group, the proportion of students who said that the practice was the effect of learning experiences was $44 \%$, and there were no students saying that there was no effect. In the second group, the rate of students who said that learning was the effect of learning was $19 \%$, and the students who did not have effect was $15 \%$.

\section{Discussion and Conclusion}

The method applied from the pre-service primary teachers' answers, from the works they have done and from the way they evaluate them shows that in the course of teaching visual arts, the course is effective and economical in the realization of the objectives and the practical purposes of the course. It is important for each participant to give different and positive answers to the questions directed to the pre-service teachers in the experimental group in order to make the practice special and appropriate for the nature of the art. In addition, the selection of such a method, which is capable of open-ended answers, is considered to be a necessary consequence of the artistic subjectivity. In the study, prospective teachers responded not only to imitations of art but also to the products they showed that they reflected the rhythm and balance of nature. When a general evaluation of the responses of the pre-service teachers was made, it was observed that the participants looked at the artistic application studies with a different perspective and there was a sensitivity increase to see them apart from the reflective approach. When a general evaluation of the responses of the prospective teachers was made, it was observed that the participants looked at the artistic application studies with a different perspective and there was a sensitivity increase to see them apart from the reflective approach. From the findings of the research as a result of the application, it is seen that the participants think that the study is useful for the pre-service teachers. From the findings of the research as a result of the application, it is seen that the participants think that the study is useful for the teacher candidates. As a result, it can be said that the activities of pre-service teachers about artistic practice will have positive effects on their professional lives. 


\section{Giriş}

Son yıllarda sanat öğretimi alanında yeni ve çağdaş yaklaşımlar sanat eğitimini kendi disiplinleri olan ve öğretilebilir boyutta ele alan yeni bakış açıları ile önem kazanmaktadır. Bu yönüyle sanatsal öğrenme, artık yetenekten çok düşüncenin organize edilip yorumlandığı, yaratıcılık ile birleştiği bir öğrenme alanıdır. Yeni yönelimlerle sanat eğitimi, ustalık beceri ve yetenekten çok malzemeyi ve imkânları tanıma ve keşfetmeye dönük etkinlikler ve öğretilebilir bir disiplin alanı olarak sınırlarını genişletmektedir. Bu çağdaş yaklaşımların benimsenmesi ve yaygınlaşması için, yeni yönelimleri yansıtan sanatsal üretim uygulamalarının geliştirilmesine ihtiyaç vardır.

Günümüzdeki bu çağdaş eğilimler sayesinde, sanatsal öğrenmenin yapabilme ve yaptığını sözel olarak da ifade edebilme ile gerçekleşebileceğine inanılmakta bu da nesnel olmayı zorunlu kılmaktadır. Sanatsal eğitimimizde hedeflendiği gibi; sanattan anlayan, eser alımlayabilen ve bu yolla yaşadığı kültüre katkı yapan bireyler yetiştirmek istiyorsak, bu hedeflerin gerçekleşmesine katkı sağlayacak araştırmalara ve bulguların paylaşılmasına ihtiyaç vardır.

Bu çalışma görsel sanatlar öğretimi dersi için geliştirilen ve uygulanan bir metodun öğrenci tutumuna etkilerini değerlendirme ile sınırlıdır. Bu metot ile aşılabileceğini düşünülen öğrenci kaygı ve tutumlarından kaynaklı engeller üzerinde durulmuş, öğrencilerin bu kaygılarından kurtulması ve olumlu tutum geliştirmesini sağlamak çalışmanın temelini oluşturmuştur.

$\mathrm{Bu}$ engellerin başında öğrencilerin sanatla ilgili inanç ve tutumları ile ilkesel sorunlar gelmektedir. İlkesel sorunlar; yeteneğin ön plana çıkarılması, öğretimin yalnız yeteneklilere özgü olması gerektiği gibi yaygın kanılardan oluşmaktadır (Kırışoğlu, 2002:3). Bu yaygın kanılar, geleneksel beklentiye uygun (yani gerçeğe yakın, yansıtmacı) anlayışta resim yapabilme gereğine inancı beslemekte ve kaygı oluşturmaktadır. Öğrencilerin tutumları inançlarıyla ve davranışlarıyla yakından ilişkilidir. Bu yüksek ve gereksiz beklenti nedeniyle öğrenci dersi kendinden uzak ve öğrenilemez görmektedir. Sanat eğitimi öncelikle anlamayı ve inanmayı gerektirmektedir. Pajares inançların doğrudan gözlenemeyeceğini, bunların insanların söylediklerinden, niyetlerinden ve yaptıklarından çıkarılabileceğini belirtmektedir (Bıkmaz, 2002:200). Bu nedenle duyuşsal alanda gerçekleşen sanatsal öğrenme ile ilgili değerlendirme öğrencilerin gerçekleştirdikleri uygulamaların sonuçlarından ve araştırma sorularına verdikleri yanıtlardan oluşturulmuştur.

Duyuşsal öğretme stratejileri öğrenmede duyusal ve güdüsel engelleri kaldırmaya yardım eden stratejilerdir (Senemoğlu,1997:574). Sınıf öğretmeni adaylarının sanatsal uygulamaları yeteneğe bağlı görmelerinden dolayı olumsuz tepkide bulunma eğilimlerinin bulunduğu uygulamanın başında gözlenmiş uygulama sürecinde yetenekle ilgili bu olumsuz inanç ve tutumları giderilmek ve dersin hedeflerini gerçekleştirmek çalışmanın başlangıç noktasını oluşturmaktadır.

\subsection{Araştırmanın Amacı ve Önemi}

Çalışmanın sınıf öğretmeni olarak görev yapacak ve ilkokullarda Görsel Sanatlar derslerini yürütecek olan sınıf öğretmeni adaylarının, dersin öğretim programında belirlenen eğitimin istenen hedeflerine ulaşması amaçlanmıştır. Uygulama, ilgili öğretim programında yer alan zihinsel ve duygusal açılardan görsel sanatlar eğitiminin işlevlerini tanıma, eğitimdeki yeri ve önemi, estetik duygu ve becerilerin geliştirilmesi, çizim yoluyla görsel işitsel ve dokunsal algıda farklılaşma, resim çizme ve çizim yoluyla düşüncenin ifadesi, resim okuma ve anlatma, resim çizme tekniklerinin ders öğretim programına aktarılması hedefleri doğrultusunda gerçekleştirilmiştir.

Çalışmanın hedefleri arasında ayrıca sınıf öğretmeni adaylarının eğitiminde ileriye dönük olarak, öğretimde sanat uygulamalarının anlam ve amacı, uygulamanın birey için önemi, uygulama sürecinin önemi, uygulama ve sanat alanıyla öğrenmenin gerçekleşmesi, sanatın 
elemanlarını etkili kullanabilme ve bir yöntem bilincinin kazandırılması ve bu yolla yeteneğe dair ön yargıların yıkılması yer almaktadır.

\section{Yöntem}

$\mathrm{Bu}$ çalışma Yıldız Teknik Üniversitesi Eğitim Fakültesi Sınıf Öğretmenliği lisans programında 2017-2018 öğretim yılında, güz yarıyılında haftada 3 saat olarak işlenen Görsel Sanatlar Öğretimi dersinde gerçekleştirilmiştir. Çalışmanın birinci ve ikinci haftasında altı ders saatinde ilk uygulama tamamlanmış üçüncü hafta öğrencilerle birlikte çıktılar incelenmiş ve öğrencilere açık uçlu sorular sorularak yöneltilerek çalışma ile ilgili görüş ve düşünceleri alınmıştır. Çalışmaya birinci grupta derse devam eden 34 öğrenci ve ikinci grupta derse devam eden 26 öğrenci katılmıştır. Sorulara verilen yanıtların frekans dağılımı ile iki grubun sonuçları karşılaştırılmıştır.

Çalışma, uygulama yöntemleriyle bütünlük oluşturmakta ve öğrencilere yöneltilen sorular uygulamalara bağlı olarak anlam kazanmaktadır. Bu nedenle yöntemin uygulanabilmesi için gereğince açıklanması uygun görülmektedir. Bunu sağlayabilmek ve konuyu mümkün olduğunca daraltmak için çalışma sadece, çizgi elemanı ile kompozisyon oluşturabilme şeklinde sınırlanmıştır. Daha sonraki uygulama seanslarında pastel boya ve sulu boya teknikleri uygulanarak kompozisyon oluşturulmuştur. Bu sanatsal üretim çalışmalarında da öğrencilerin kaygılarını giderecek farklı metotlarla ders yürütülmüştür. Ancak diğer teknikler farklı soruları ve teknikleri gerektirdiğinden çalışmanın dışında tutulmuştur.

Bu çalışmada Görsel Sanatlar Öğretimi ile sınırlı olarak çözüm aranan sorular şunlardır:

1. Ögrrenciler nasıl görüyor?

2. Görme biçimleri nasıl geliştirilir?

3. Uygulama çalışmaları görme biçimleri ile nasıl ilişkilendirilir?

4. Öğrencilerin, resim yapmanın doğanın reel yansıması değil, ritmini yansıttığı algısını kazanıp kazanmadığını nasıl ölçebiliriz?

\subsection{Konunun Seçimi ve Çalışmanın Aşamaları}

\subsubsection{Birinci Grup İçin Uygulama Konusu Seçimi ve Çalışmanın Gelişimi}

Birinci gruptaki öğrencilere belli bir konu verilmemiştir. Sadece resim kağıtlarının üzerinde, o anda dinledikleri müzik ritminde çizgi çalışmaları yapmaları istenmiş; kalemi bilekten, dirsekten, omuzdan hareket ettirerek, ritim etkisindeki kalemle oluşturulan çizgilerin bir şeye benzetme amacını taşımadığı salık verilerek, estetik kaygı yerine keşfetmeye dönük teknik telkinler yapılmıştır. Bu yönlendirmeyle, öğrencilere, yaptıkları uygulamanın duyuşsal yönünü ve ritim duygusunu öğrencilerin keşfetmesini sağlayacak ortamı oluşturmak amaçlanmıştır. Çalışma kağıdında kendilerini tatmin eden örüntü oluşana kadar çalışmaya devam etmeleri sağlanmıştır. Burada öğrencilerde, resim yapmanın doğanın reel yansımasını değil, ritmini yansıttığı ile ilgili yaşantı oluşturulmaya çalışılmıştır.

Çizgiler ile yapılan örüntüler tamamlandığında, öğrencilerin görme biçimleri nasıl geliştirilir? Anahtar sorumuzun öğrenme yaşantısı oluşturulmaya çalışılmıştır. Bunu sağlayabilmek için, görsel algılarını geliştirebilecek, sanatın ilkeleri ile ilgili şu sorular sorulmuş

- Hangi çalışmada açık-koyu, ince-kalın, yukarı-aşağı, büyük-küçük, organikgeometrik farklııklar dikkati çekmektedir ve etkili şekilde kullanılmıştır?

- Hangi çalışma gözünüze daha etkili ve bütün görünmektedir, neden?

- Hangi çalışmaya uzun süre bakma ihtiyacı hissediyorsunuz (bakmak istiyorsunuz, gözünüzü alamıyorsunuz), bunun sebebi sizce nedir?

$\mathrm{Bu}$ sorularla öğrencilere problemin; bildik tanıdık biçimler yaratmak değil, sanatın elemanlarını etkili biçimde kullanmak olduğu, bunların bir şeye benzemek dışında da anlamları olduğu öğrenme yaşantısıyla vurgulanmaya çalışılmış, benzetme ile ilgili estetik kaygılardan tamamen uzaklaştırılmaya çalışılmıştır. Öğrenciler "Uygulama çalışmaları görme biçimleri ile 
nasıl ilişkilendirilir?" sorusunun cevabını bulmak için de yaptıkları örüntüye dikkatle bakmalarını ve neye benzediklerini bulmaları için yönlendirilmiş, bu noktada da çocukken izledikleri bulutların içinde hangi görüntüleri yakaladıkları sorulmuş, öğrenciler bunu coşkuyla anlatmıştır. Aynı şeyin günlük hayatta organik her oluşumda görülebileceği üzerinde durularak; fraktal yarıklar, su sızıntısı, çatlamış topraktaki ve bulutlardaki soyut oluşumlar ve tipik örneği kahve falı gibi ekspresif (istediğimiz şeye benzetebileceğimiz) örnekler çoğaltılmıştır. Bu örneklerden hareketle kendilerinin yapmış oldukları çizgi çalışmasındaki örüntülerin de bildik tanıdık nesnelere veya görünümlere dönüştürebilecekleriyle ilgili yönlendirme yapılmıştır. Böylece her öğrenci kendi görme biçimini yansıtan kendi kompozisyonunu oluşturmuştur. Burada da öğrenciler nasıl görüyor sorumuzun uygulama yaşantısını gerçekleştirmek istenmiştir. Bu aşamada kontrol altına aldıkları soyut çizgileri dönüştürtürken öğrenciler yönlendirilmiş, bulguların birbiri ile ilişkili ve yan yana anlamlı olmaları gereği hatırlatılmıştır. Örneğin; ayrı ayrı göz, burun, kulak gibi ayrı ayrı bulguların anlamlı bir kompozisyon oluşturamayacağı, uzuvları portre ile bir araya getirilerek bütünleşebileceği veya uzakta bir nesne yaparsak, öndeki nesnelerin daha küçük değil, arkadakinden daha büyük olması gerektiği gibi yanılsama ile ilgili hatırlatmalar yapılmış, görme biçimlerine göre konularında serbest bırakılmışlardır. Böylece öğrencilerin kendi kompozisyonlarını oluşturdukları ve görme biçimlerini kullanarak kompozisyon oluşturabildikleri görülmüştür.

\subsection{2. İkinci Grup İçin Uygulama Konusu Seçimi ve Çalışmanın Gelişimi}

İkinci grup öğrencilere çizgi çalışmasına uygunluğu gerçekleştirmek ve bütünlüğü sağlayabilmek için siyah-beyaz fotokopileri alınmış çok küçük $(2 \times 2 \mathrm{~cm})$ görsel parçalar kesilerek dağıtıımıştır. Seçtikleri bu küçük parçaları resim kâğıtlarına yapıştırarak hayal güçleri ile tamamlamaları ve bundan hareket ederek çizgi elemanı ile kompozisyon oluşturmaları istenmiştir. Böylece ikinci grup küçük bir parçadan, birinci grup ise elinde hiçbir şey olmadan kendi oluşturduğu soyut örüntülerden yola çıkarak kompozisyon oluşturmuştur. İkinci grup öğrencilerin çalışma metodu da dersin amaçlarına uygun olarak planlanmış ve uygulama ile ilgili güdülemeler yapılmış, öğrenciler cesaretlendirilmiştir.

Çalışmalar tamamlandığında birinci gruba; hangi çalışmada örüntü sağlanmış, hangi çalışmada sanatın elemanları etkili kullanılmış, gibi sorular sorulmaya çalışımış, ancak birinci grupta sorulara gösterilen ilgi, ikinci grupta aynı şekilde gerçekleşmemiştir. Bu gruptaki öğrenciler; klasik uygulama çalışmalarında olduğu gibi, konuyu tamamlama kaygısı ile sanatın elemanlarına değil yaptıkları temaya ve resimde ne olduğuna, neye benzediğine odaklanmış ve bir şeye benzetme kaygısında oldukları görülmüştür.

Öğrenme yaşantıları yoluyla, öğrencilerin uygulama olayına karşı olumlu davranış geliştirme eğilimi ve duygu düşünce bütünleşmesini gerçekleştirebilmek için, uygulama süresince öğrenci merkezde tutularak çizmeyi öğrenmesi değil, keşfetmesi yönünde çaba harcanmıştır. Her iki grubun da uygulama süresince coşkuyla katılım yaptığı ve çalışmayı sürdürdüğü görülmüş, aralarındaki farklı kazanımların belirlenmesi için, her iki gruba geliştirilen aynı açık uçlu sorular sorulmuştur. Cevapların değerlendirilmesinden sonuca varılmaya çalışılmış ve bulgular bölümünde açıklanmıştır.

$\mathrm{Bu}$ araştırma deneysel bir çalışmadır. Araştırmada verilerin toplanmasında kullanılan sorular araştırmacılar tarafından dersin hedeflerine uygun olarak geliştirilmiştir. Bu araştırma bir durum incelemesi niteliğinde olup, uygulama sonrası betimsel analiz modeli içinde yürütülmüştür. Öğrencilerin sorulara verdiği yanıtlar frekans (f) ve yüzde tabloları halinde sergilenerek yüksek puandan düşük puana doğru betimsel yorumları yapılmıştır.

\section{Bulgular}

Araştırmaya katılan öğrencilere ilk olarak uygulama ile ilgili önceki deneyimlerinin olup olmadığı sorularak derse ne kadar yakın oldukları anlaşılmaya çalışılmıştır. Bu boyutun bulguları aşağıdaki gibidir. 
Temel Eğitim Dergisi / Journal of Primary Education, 2019, 1(1), 27-39

\subsection{Uygulama ile İlgili Olarak Öğrencilerin Önceki Deneyimleri}

Öğrencilere ilk olarak "Daha önce uygulama çalışmasında bulundunuz mu?" sorusu yöneltilmiştir. Öğrencilerin bu soruya verdikleri yanıtların frekansları ve yüzdeleri Tablo 1'de verilmiştir.

Tablo 1. Soruya verilen yanıtların frekans (f) ve yüzde tabloları

\begin{tabular}{lcccc}
\hline & \multicolumn{2}{c}{ 1. Grup } & \multicolumn{2}{c}{ 2. Grup } \\
\cline { 2 - 5 } & $\mathrm{f}$ & $\%$ & $\mathrm{f}$ & $\%$ \\
\hline $\begin{array}{l}\text { Daha önce uygulama çalışmasında } \\
\text { bulunmayan }\end{array}$ & 25 & 73 & 17 & 65 \\
\hline Daha önce uygulama çalışmasında bulunan & 9 & 26 & 9 & 34 \\
\hline
\end{tabular}

Öğrencilerin uygulama geçmişini öğrenme amacıyla sorduğumuz soruya birinci grup öğrencilerin \%73'ü ilkokuldan sonra, hatta ilkokulda bile hiç uygulama yapmadıklarını, \%26'sı en son ortaöğretimde uygulama çalışmasında bulundukları yanıtını vermiştir. İkinci gruptaki öğrencilerin \%65'i ilkokuldan sonra uygulama yapmadıklarını, \%34'ü uygulama çalışmasında bulunduğunu belirtmiştir. Bu oranlar bizde sanat eğitiminin önemsenmediği, önemli ve gerekli görülmediği düşüncesini oluşturmaktadır. Oysa her ders insanın bir açı̆̆ını kapatmak için vardır.

Bu oranlarla hem nicel, hem de nitel olarak, sanatsal üretim uygulamalarının yeterli düzeyde olmaktan uzak olduğu söylenebilir. Bu tablodaki veriler öğrencilerin açıklarını kapatacak ve dersin hedeflerini gerçekleştirecek güvenilir ve ekonomik yöntemlere intiyaç olduğunu göstermektedir.

\section{2. Öğrencilerin Uygulama Sürecindeki Duygu ve Düşünceleri}

$\mathrm{Bu}$ aşamada öğrencilere "Uygulama yaparken kendinizi nasıl hissettiniz?" sorusu yöneltilmiştir. Öğrencilerin bu soruya verdikleri yanıtların frekansları ve yüzdeleri Tablo 2'de verilmiştir.

Tablo 2. Soruya verilen yanıtların frekans (f) ve yüzde tabloları

\begin{tabular}{|c|c|c|c|c|}
\hline & \multicolumn{2}{|c|}{$\begin{array}{c}\text { 1.Grup } \\
\text { Çizgi } \\
\text { Çalışması yapanlar }\end{array}$} & \multicolumn{2}{|c|}{$\begin{array}{c}\text { 2.Grup } \\
\text { Tamamlama } \\
\text { Çalışması yapanlar }\end{array}$} \\
\hline & $f$ & $\%$ & $f$ & $\%$ \\
\hline \multicolumn{5}{|l|}{ Uygulamanın başında } \\
\hline Heyecanlı & 6 & 17 & 5 & 19 \\
\hline Korku-kaygı- umutsuzluk & 4 & 11 & 14 & 53 \\
\hline Rahat & 4 & 11 & - & - \\
\hline Meraklı & 4 & 11 & - & - \\
\hline Mutlu & 3 & 8 & $\ldots$ & - \\
\hline Endişeli & 3 & 8 & 4 & 15 \\
\hline Özgür & 3 & 8 & - & - \\
\hline Şaşkın-Karışık & 3 & 8 & - & - \\
\hline Karamsar & 2 & 5 & 3 & 11 \\
\hline Yetersiz & - & - & 1 & 3 \\
\hline Kararsız & - & - & 1 & 3 \\
\hline Düşünceli & - & - & 1 & 3 \\
\hline Umutsuz & - & - & 1 & 3 \\
\hline \multicolumn{5}{|l|}{ Çalışmanın Ortasında } \\
\hline Kendime inancım ve hâkimiyetim arttı & 6 & 17 & - & - \\
\hline
\end{tabular}


Temel Eğitim Dergisi / Journal of Primary Education, 2019, 1(1), 27-39

\begin{tabular}{lcccc} 
Rahatladım & 4 & 11 & - & - \\
\hline $\begin{array}{l}\text { Geliştiğimi hissettim, daha iyi } \\
\text { görüyordum }\end{array}$ & 4 & 11 & - & 26 \\
\hline Keyifliydim, zevk aldım & 4 & 11 & 7 & - \\
\hline Heyecanlandım & 2 & 5 & - & - \\
\hline Anlamlı buldum & 1 & 2 & - & - \\
\hline Gurur duydum & 1 & 2 & - & - \\
\hline Çok mutlu oldum & 1 & 2 & - & - \\
\hline Güven duydum & 1 & 2 & - & 34 \\
\hline Gergin ve kararsızdım & - & - & 9 & 19 \\
\hline Kendimi yetersiz hissettim & - & - & 5 & 38 \\
\hline & & & & 30 \\
\hline Sevinç-Güven & 20 & 58 & 10 & 3 \\
\hline Mutlu ve Başarılı & 13 & 38 & 8 & 19 \\
\hline Keyifli ve zevkli & 4 & 11 & 1 & - \\
\hline Güvenim Arttı & 5 & 14 & 5 & 15 \\
\hline Rahatlamış, arınmış, huzurlu & 3 & 8 & - & 7 \\
\hline Kendimi keşfettim & 1 & 4 & 4 & 2 \\
\hline Üzüldüm-moralim bozuldu & 2 & 5 & & \\
\hline
\end{tabular}

Uygulama sürecinin başında, ortasında, sonunda kendinizi nasıl hissettiniz sorusu öğrencilerin kendi ifadelerini anlamlandırmak amacıyla açık uçlu sorulmuştur. Bulgular incelendiğinde; sürecin başında kendini heyecanlı hisseden öğrencilerde anlamlı fark olmadığı ancak ikinci gruptaki öğrencilerin \%15 oranında endişeli hissetmesi, \%53 oranında korkukaygı-umutsuzluk hissetmesi yüksek bir orandır. Metot farklılığını göz önüne alarak, bu oranın yüksek olmasının sebebinin gerçekçi çizimler yapma kaygısından yani estetik kaygıdan kaynaklandığını söyleyebiliriz. Aynı şekilde bu grupta hiç kimsenin kendini rahat, mutlu ve meraklı görmediğini anlıyoruz. Yine bu grupta hiç bir öğrencinin kendini özgür hissetmediğini, \%11'inin kendini karamsar hissettiğini görüyoruz. Yetersiz, kararsız, düşünceli, umutsuz olan kişilerin toplamının 4 olduğunu ve bunun frekans dağılımının \%11 olduğu da göz önüne alınırsa, birinci gruptaki öğrencilerin çalışmaya biraz daha uyumlu başladığını söyleyebiliriz, ancak burada çok büyük bir fark görülmemektedir.

Çalışmanın ortasına geldiğimizde ikinci grubun, birinci gruba göre iki katı oranda daha çok keyif aldığını anlıyoruz. Bunun sebebinin ellerindeki küçük parçayı tamamlayabileceklerine olan güvenleri olabilir. Diğer yandan, öğrencilerin keyifli bulması için tutumlarında farklılık olması gereği de olmayabilir. Ancak birinci gruptaki öğrencilerin konusuz ve temasız çalışmayla çözecekleri problemi kendilerinin oluşturmuş olmaları ve aralarında heyecanlı, anlamlı, gururlu, mutlu olanların olması, inancım ve hâkimiyetim arttı demeleri derse karşı tutumlarında olumlu anlamda farklılıklar olduğunu göstermektedir. Buna karşılık ikinci grupta \%34 oranında gergin ve karamsar olan öğrenci ile birlikte \%34 oranında da endişeli öğrencilerin olduğu görülmektedir. Öğrencilerin \%19'unun ise kendilerini yetersiz hissettikleri görülmüştür.

Çalışma sürecinin ortasında, öğrencilerden aldığımız cevapların frekans dağılımları, birinci gruptakilerin daha verimli uygulama yaptıklarına inandıklarını göstermektedir.

Çalışmanın sonunda neler hissettiklerine baktığımızda; öğrencilerin sevinç ve güven duygusu hissetme oranının birinci grupta \%58, ikinci grupta \%38 olduğu, birinci grupta \%38 olan mutlu ve başarılı hissetme oranının ikinci grupta \% 30 olduğu, kendini keyifli hissedenlerin birinci grupta \%11 iken, ikinci grupta \%3 olduğu, birinci grupta \% 8'i rahatlamış, huzurlu, arınmış hissederken, ikinci grupta kimsenin bunu hissetmemesi gibi değerler birinci metodun öğrenci tutumlarının değişmesi ve gelişmesinde daha etkili olduğunu göstermektedir. Güvenim arttı, kendimi keşfettim diyen öğrencilerin yüzde oranlarının, ikinci grupta daha çok olması da 
Temel Eğitim Dergisi / Journal of Primary Education, 2019, 1(1), 27-39

beklentiye uygun çalışma metotlarının da öğrenciler üzerinde olumlu etkiler bıraktığını göstermektedir.

2. tabloya bütün olarak baktığımızda verilen cevaplardan, birinci gruptaki öğrencilerin, çalışmanın ortasındaki ve sonundaki duygularının olumlu tutum değişikliğine zemin oluşturduğunu ve dersin hedeflerine dönük çizgi çalışması ile uygulanan metodun daha etkili olduğunu söyleyebiliriz.

\section{3. Öğrencilerin Uygulamadan Sonraki Duygu ve Düşünceleri}

Öğrencilere "Sizce çalışmanız özgün mü, taklit mi, neden?" sorusu yöneltilmiştir. Öğrencilerin bu soruya verdikleri yanıtların frekansları ve yüzdeleri Tablo 3'te verilmiştir.

Tablo 3. Soruya verilen yanıtların frekans (f) ve yüzde tabloları

\begin{tabular}{|c|c|c|c|c|}
\hline & \multicolumn{2}{|c|}{ 1. Grup } & \multicolumn{2}{|c|}{ 2. Grup } \\
\hline & $\mathrm{f}$ & $\%$ & $\mathrm{f}$ & $\%$ \\
\hline Özgün & 34 & 100 & 19 & 73 \\
\hline Sadece kendi iç dünyamın ürünü & 4 & 11 & & 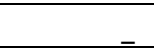 \\
\hline Hiçbir yere bakmadım & 5 & 14 & - & - \\
\hline Ben kendim yaptım & 4 & 11 & - & - \\
\hline Hiçbir kurala uymuyor özgün & 2 & 5 & - & - \\
\hline Kendi hayal gücümün ürünü & 3 & 8 & - & - \\
\hline Hayal gücümle tamamladım & - & - & 2 & 7 \\
\hline Çevremdekiler farklı olduğunu söylüyor & - & - & 1 & 3 \\
\hline Küçük parçayı ben geliştirdim & - & - & 1 & 3 \\
\hline Özgün değil & - & - & 5 & 19 \\
\hline Fikir bana ait değil & - & - & 1 & 3 \\
\hline Taklide dayalı internete baktım & - & - & 1 & 3 \\
\hline Var olan parçadan gittim, özgün değil & - & - & 1 & 3 \\
\hline
\end{tabular}

Bu soruyla öğrencilerin sanatsal üretimi özgün eserle ilişkilendirebilme ile ilgili algılarını ölçmek amaçlanmıştır. Sanat eğitiminin en çok zorlandığı; realist olan, gerçeğe benzeyen, öğrenilmiş şeylere olan hayranlığı yıkarak, keşfetmeye dönük bakış açısı geliştirebilmektir. Bu açıdan bakıldığında birinci grup için geliştirdiğimiz metodun \%100 başarılı olduğunu, ikinci grupta bu oranın \%75 olması da çalışmanın her iki grupta da önemle ele alındığını ve dersin amacına ulaştığını göstermektedir. İkinci grupta \%19 oranında çalışmalarının özgün olmadığını düşünen öğrenci olması, bunun sebeplerinin; internete baktım, var olan parçadan yaptım, fikir bana ait değil gibi çeşitli gerekçeler sıralamaları, küçük bir parçayı kullanmalarının alıntı fikrini oluşturduğunu, öğrencilerin kendi oluşturdukları kompozisyonları yapabilmeyi tercih ettiğini ve buna önem verdiğini ifade etmektedir.

Tablo3'ün genel değerlendirmesi için, dersin amacına ulaşmasında geliştirdiğimiz metotla çalışan birinci grubun belli bir oranla daha başarılı olduğunu söyleyebiliriz.

\section{4. Öğrencilerin Uygulama Sonrası "Yaratıcılık" ile İlgili Duygu ve Düşünceleri}

Öğrencilere "Size göre çalışmanız yaratıcı mıydı?" sorusu yöneltilmiştir. Öğrencilerin bu soruya verdikleri yanıtların frekansları ve yüzdeleri Tablo 4'te verilmiştir. 
Temel Eğitim Dergisi / Journal of Primary Education, 2019, 1(1), 27-39

Tablo 4. Soruya verilen yanıtların frekans (f) ve yüzde tabloları

\begin{tabular}{lcccc}
\hline & \multicolumn{2}{c}{ 1. Grup } & \multicolumn{2}{c}{ 2. Grup } \\
\cline { 2 - 5 } & $\mathrm{f}$ & $\%$ & $\mathrm{f}$ & $\%$ \\
\hline Çalışmam yaratıcıydı & 26 & 76 & 16 & 57 \\
\hline Yaratıcı değildi & - & - & 6 & 23 \\
\hline
\end{tabular}

Birinci grupta geliştirdiğimiz uygulama metodu doğrultusunda çalışan öğrenciler \%76 oranında çalışmasını yaratıcı bulmakta, ikinci grupta tamamlama çalışması yapanlarda bu oran \%57'ye düşmekte ve ayrıca \%23 oranında çalışmasını yaratıcı bulmayan öğrenci bulunmaktadır. Bu yüzde oranları da geliştirdiğimiz ve birinci grupta uyguladığımız çalışma metodunun öğrencilerin yaratıcılıklarının gelişmesinde de etkili olduğunu göstermektedir.

\section{5. Öğrencilerin Uygulama Öncesi ve Sonrası "Kazanımlar" ile İlgili Düşünceleri}

Öğrencilere "Görsel Sanatlar Öğretimi Dersindeki uygulamanın öğrenme yaşantınıza etkisi oldu mu?" sorusu yöneltilmiştir. Öğrencilerin bu soruya verdikleri yanıtların frekansları ve yüzdeleri Tablo 5'te verilmiştir.

Tablo 5. Soruya verilen yanıtların frekans (f) ve yüzde tabloları

\begin{tabular}{|c|c|c|c|c|}
\hline & \multicolumn{2}{|c|}{ 1. Grup } & \multicolumn{2}{|c|}{ 2. Grup } \\
\hline & $f$ & $\%$ & $\mathrm{f}$ & $\%$ \\
\hline Etkisi oldu & 15 & 44 & 5 & 19 \\
\hline Etkisi olmadı & - & - & 4 & 15 \\
\hline Farklı bakış açısı kazandım & 1 & 4 & 1 & 3 \\
\hline $\begin{array}{l}\text { Resimde önemli olanın güzel değil, özgün olması } \\
\text { gerektiğini öğrendim }\end{array}$ & 1 & 4 & - & - \\
\hline $\begin{array}{l}\text { Artık çocukların resimlerini daha iyi anladığımı fark } \\
\text { ettim }\end{array}$ & 1 & 4 & - & - \\
\hline $\begin{array}{l}\text { Resmin çizgi elemanına hâkim oldum, çizginin gücünü } \\
\text { öğrendim }\end{array}$ & 1 & 4 & - & - \\
\hline Bakmadan çizebilme fikrim oluştu & 1 & 4 & - & - \\
\hline Hayal gücüm zenginleşti & 1 & 4 & 1 & 3 \\
\hline Kendimi daha kültürlü hissediyorum & 1 & 4 & - & - \\
\hline $\begin{array}{l}\text { Her beğendiğime sanatsal diyordum, sanat ürünü } \\
\text { taklit değilmiş }\end{array}$ & 1 & 4 & - & - \\
\hline Bana çok şey kattı & 1 & 4 & - & - \\
\hline $\begin{array}{l}\text { Tabi oldu, hem kendi çalışmamdan, hem de } \\
\text { arkadaşlarımın çalışmalarından farklı bakış açıları } \\
\text { kazandım }\end{array}$ & 1 & 4 & - & - \\
\hline $\begin{array}{l}\text { Hem okul deneyiminde hem işimde hem de özel } \\
\text { hayatımda işime yaradı }\end{array}$ & 1 & 4 & - & - \\
\hline Çevreye ve nesnelere bakış açım değiști & 1 & 4 & 2 & 7 \\
\hline Artık resim konusunda çok yetersiz değilim & 1 & 4 & - & - \\
\hline Sanatın ilkelerini incelemeyi öğrendim & 1 & 4 & - & - \\
\hline Günlük hayatta resmin elemanlarını görür oldum & 1 & 4 & - & - \\
\hline Çocuklara en iyi şekilde öğretmeyi hedefledim & 1 & 4 & - & - \\
\hline Sanatın ruhunu anlamaya başladım & 1 & 4 & - & - \\
\hline Açık koyu değerlerin anlamını gördüm & 1 & 4 & - & - \\
\hline $\begin{array}{l}\text { Yorum kabiliyetim gelişti, cesur ve yaratıcı olmayı } \\
\text { öğrendim }\end{array}$ & 2 & 5 & - & - \\
\hline Yorumlamalardan çok şey öğrendim & 2 & 5 & - & - \\
\hline $\begin{array}{l}\text { Estetik bakış açısı geliştirdim, tekdüzelikten } \\
\text { kurtuldum }\end{array}$ & 2 & 5 & - & - \\
\hline
\end{tabular}


Temel Eğitim Dergisi / Journal of Primary Education, 2019, 1(1), 27-39

\begin{tabular}{llllc}
\hline Keşfetmeyi öğrendim & - & - & 1 & 3 \\
\hline Özgüvenim arttı & - & - & 1 & 3 \\
\hline Tamamlama çalışmasını yapabildim & - & - & 3 & 11 \\
\hline Yaparken düşündüm & - & - & 1 & 3 \\
\hline Öğrencilerimin ruhlarına dokunacağım & - & - & 1 & 3 \\
\hline Önyargım gitti & - & - & 1 & 3 \\
\hline Perspektifi öğrendim & - & - & 1 & 3 \\
\hline Fikirlerimi kullandım & - & - & 1 & 3 \\
\hline $\begin{array}{l}\text { Çalışmaya müdahale edilmemesi gerektiğini } \\
\text { öğrendim }\end{array}$ & - & - & 2 & 7 \\
\hline Yapabilme inancı kazandım & - & - & 1 & 3 \\
\hline
\end{tabular}

Birinci grupta uygulamanın öğrenme yaşantımıza etkisi oldu diyen öğrencilerin oranı \%44 olup, etkisi olmadı diyen hiçbir öğrenci yoktur. Bu gruptaki öğrencilerin önemli olanın güzel değil, özgün olması gerektiğini öğrendim; artık çocukların resimlerini daha iyi anladığımı fark ettim; her beğendiğime sanatsal diyordum, sanat ürünü taklit değilmiş; kendimi daha kültürlü hissediyorum; hem deneyim okulunda, hem işimde, hem de özel hayatımda işime yaradı; çevreye ve nesnelere bakışım değişti; artık resim konusunda çok yetersiz değilim şeklindeki ifadeleri uygulamanın bu öğrenciler için ne kadar etkili bir uygulama olduğunu göstermektedir. Tek tek öğrencilerin kazanımlarını kendi cümleleri ile ifade edebilmeleri, farkındalıklarının ne kadar geliştiğinin de önemli bir ifadesidir.

İkinci grupta öğrenme yaşantıma etkisi oldu diyen öğrencilerin oranı \%19 olup, \%11 oranında tamamlama çalışmasını yapabildim ifadesi ile bir şey yapabilmenin tek amaç olduğu bunun da kaygının artmasına ve hedefin daralmasına sebep olmuş olacağı muhtemeldir. \%7 oranında çalışmaya müdahale edilmemesini öğrendim ifadesi öğrencinin kendi öz çıkarımı olup araştırmamızla ilgisi olmayan önemli bir kazanımdır. Ikinci grupta uygulamanın öğrenme yaşantısına etkisi olmadı diyenlerin oranı da \%15 olmuştur. Birinci grupta etkisi olmadı diyen öğrenci bulunmadığı düşünülürse uyguladığımız metodun dersimizin amacını gerçekleştirmede etkili olduğu söylenebilir.

\section{6. Öğrencilerin Uygulama ile Kazandıkları Bilişsel Kazanımları}

Öğrencilere "çalışmanızda hangi sanat elemanlarını kullanarak, hangi ilkeleri oluşturduğunuzu çalışmanıza bakarak yazınız" sorusu yöneltilmiştir. Öğrencilerin bu soruya verdikleri yanıtların frekansları ve yüzdeleri Tablo 4'te verilmiştir.

Tablo 6. Soruya verilen yanıtların frekans (f) ve yüzde tabloları

\begin{tabular}{lccccc}
\hline & & \multicolumn{2}{c}{ 1, Grup } & \multicolumn{2}{c}{ 2.Grup } \\
\cline { 2 - 5 } & Elemanlar & $\mathrm{f}$ & $\%$ & $\mathrm{f}$ & $\%$ \\
\hline Çizgi & & & & \\
\hline Nokta & 22 & 64 & 18 & 69 \\
\hline Form & 1 & 2 & 8 & 30 \\
\hline Desen & 1 & 2 & 4 & 15 \\
\hline Şekil & 1 & 2 & - & - \\
\hline Örüntü & & 11 & 9 & 34 \\
\hline Doku & & 4 & 11 & 6 & 23 \\
\hline & & 4 & - & 2 & 7 \\
\hline Zıtlık & İlkeler & - & & & \\
\hline Vurgu & & 14 & 41 & 5 & 19 \\
\hline Ritim & 14 & 41 & 12 & 46 \\
\hline
\end{tabular}


Temel Eğitim Dergisi / Journal of Primary Education, 2019, 1(1), 27-39

\begin{tabular}{lcccc}
\hline Birlik-bütünlük & 6 & 17 & 2 & 7 \\
\hline Uyum & 1 & 2 & - & - \\
\hline Kompozisyon & 4 & 11 & - & - \\
\hline Denge & 2 & 5 & 1 & 3 \\
\hline Hareket & - & - & 6 & 23 \\
\hline Oran-Orantı & 2 & 5 & 1 & 3 \\
\hline Hareket & - & - & 6 & 23 \\
\hline Bilmiyorum & - & - & 1 & 3 \\
\hline Işı-gölge & - & - & 5 & 19 \\
\hline
\end{tabular}

Sanatın elemanlarını tanıma, terminoloji olarak da kullanabilme, ilkelerini çalışma üzerinde oluşturma ve gösterebilme her iki grup tarafından az hata ile anlaşılmış anlamlı bir fark görülmemiştir.

\section{Tartışma ve Sonuç}

Araştırma iki haftada, haftalık üç ders saati ile gerçekleştirilen uygulamaların üçüncü haftada katılımcılara yöneltilen açık uçlu soruların değerlendirilmesi ile gerçekleştirilmiştir. Sorulara verilen yanıtlar ve frekans dağılımları tablolarla gösterilmiş ve veriler yorumlanmıştır. Çalışmaların verileri altı tabloda toplanmıştır. İlk tablo metotla doğrudan ilgisi olmamakla beraber çalışmada ve tüm sanat eğitiminde göz önüne alınması gereken bir durum tespitini ortaya koymaktadır. İkinci, üçüncü, dördüncü ve beşinci tablolardaki frekans dağılımları uygulanan metodun etkili olduğunu göstermektedir.

Bireylerin sanat alanında duyusal algıları ile ilgili değişim ve gelişmelerini ölçmek bilişsel bir durum tespiti ortaya koymadığından, ancak bireylerin yaptıkları ve tutumları ile ölçülebilmektedir. Tutumları da söyledikleri ve yaptıklarıyla ilişkilidir. Bu nedenle çalışma öğretmen adaylarının sorulara verdikleri yanıtlar ile söylemlerini anlamlandırmaya çalışma ve bunu yaptıkları ürünler ile destekleme aşamalarıyla gerçekleştirilmiştir.

Öğretmen adaylarının yanıtlarından, yaptıkları çalışmalardan ve onları değerlendirme biçimlerinden uygulanan metodun görsel sanatlar öğretimi dersinde, dersin hedeflerinin ve uygulama amaçlarını gerçekleşmesinde etkili ve ekonomik olduğunu göstermektedir.

Deney grubundaki öğretmen adaylarına yöneltilen sorulara her katılımcının birbirinden ayrı ve olumlu cevaplar vermiş olması, uygulamanın sanatın doğasına uygun olarak özelleşmesi ve anlam kazanması açısından önemlidir. Ayrıca açık uçlu cevaplar edinilebilen böyle bir metodun seçilmiş olması, sanatın öznelliğinin zorunlu bir sonucu olarak düşünülmektedir. Çalışmada öğretmen adayları sanatın taklit değil, doğanın ritim ve dengesini yansıttığı konusunda ortaya koydukları ürünlerle de cevap vermişlerdir.

$\mathrm{Bu}$ çalışmada kapsamında gerçekleştirilen uygulamalar öğretmenlerin neyi nasıl öğretecekleri ile ilgili bir yaklaşım ortaya koymak yerine sınıf öğretmeni adaylarının sanatın zengin evrenine girmelerine de olanak vermektedir. Öğretmen adaylarının lisans düzeyinde bir eğitimde küçük çocukların düzeyinde çalışmalar yapmaları sanatı ve doğasını anlamaktan uzak bir tutum oluşturmaktadır. Eğitim açısından resim yapmak doğanın insana verdiği bir anlatım aracı, yaşanması ve tanınması gereken bir öğrenme yaşantısıdır. Reçeteleri olan yöntemler bütünü değildir. Keşfedilerek bulunan, bireydeki bir değerdir. Bu nedenle öğretmen adaylarına, gelecekteki öğrencileri ile yapacakları çalışmaların minyatürünü yaptırmak gibi yaklaşımlar eğitim ve sanat dışıdır.

Öğretmen adaylarının vermiş oldukları yanıtların genel bir değerlendirmesi yapıldı̆̆ında, katılımcıların sanatsal uygulama çalışmalarına farklı bir gözle baktıkları ve yansıtmacı anlayış dışında görmeye ilişkin bir duyarlııı artışı olduğu gözlenmiştir.

Uygulama sonucundaki araştırma bulgularından katıımcıların, çalışmanın öğretmen adaylarına faydalı olduğunu düşündükleri görülmektedir. Bu durumda birey bir tutumu, kendisine psikolojik işlev ya da yarar sağladığında seçtiğinden sınıf öğretmeni adaylarının 
Temel Eğitim Dergisi / Journal of Primary Education, 2019, 1(1), 27-39

sanatsal uygulama ile ilgili çalışmalarının meslek yaşantılarında olumlu etkiler yapacağı söylenebilir.

\section{Kaynaklar}

Bıkmaz, F. H. (2002). Fen öğretiminde öz-yeterlik inancı ölçeği eğitim bilimleri ve uygulama, II, Ankara.

Kırışoğlu, O. T. (2002). Sanatta eğitim görmek, öğrenmek, yaratmak. Ankara: Pegem A Yayınları.

Senemoğlu, N. (1997). Gelişim öğrenme ve öğretim: kuramdan uygulamaya. Ankara: Ertem Matbaacilık. 